Pakistan Journal of Education

Vol.36, No.2, 2019, 137-163

\title{
Prospective Teachers' Perceptions of Oral Presentations: An Exploration of Challenges Involved
}

\author{
Zafar Iqbal * \\ Effat Alvi ${ }^{* *}$ \\ Farhat Shafi $^{* * *}$
}

\begin{abstract}
Presentation skills are considered as one of the most important proficiencies needed for higher education and future careers for teachers. The present study identifies the challenges faced by prospective teachers during classroom oral presentations while studying at a teacher training institute, Institute of Education and Research, (IER). The participants of the study were 400 prospective teachers enrolled in different programs of teacher education at IER. Independent variables were number of semesters already completed at the institute, gender and GPA in the completed semesters. A questionnaire was developed comprising three main sections: personal traits, oral presentation skills and peers and teachers. The statements were developed on a five-point Likert Scale to know the opinion of prospective teachers regarding challenges involved in oral presentations. In addition, a semi-structured interview was conducted from thirty prospective teachers to probe results obtained from quantitative analysis and investigate reasons behind emerging challenges. The findings revealed that prospective teachers experienced medium level of difficulties in oral presentations with mild tendency towards high rank. There was no significant difference found in the results regarding the number of semester students already completed, GPA and gender in general, whereas, statistically significant difference was found on factor peer and teachers with respect to variable gender only. Analysis of qualitative data revealed tangible reasons behind the challenges of oral presentations such as second language, personal traits and use of technology. There is a need to encourage sharing of ideas, discussions and presentations in the classrooms right from the early years of school through higher education in order to enable learners to become confident, vocal and effective teachers.
\end{abstract}

Keywords: oral presentation; classroom assessment; teacher training

\footnotetext{
* Distance Non-formal and Continuing Education, Allama Iqbal Open University, Islamabad. Email: zafarar72@yahoo.com

${ }^{* *}$ Institute of Education and Research, University of the Punjab, Lahore, Pakistan

*** Graduate, IER, University of the Punjab, Lahore, Pakistan
} 


\section{Introduction}

One of the most important skills needed for higher education and future prospects of learners regardless of discipline or professional choice is oral presentations (Campbell et al., 2001; Morley, 2001; Thorn bury, 2005). The importance of oral presentations that is often termed as public speaking has been recognized widely around the globe (Harmen, 2010). This is because the advancements in information and communication technologies, internet and World Wide Web have urged the sharing of knowledge, cultures and values. It is thus, important to develop proficiency in communication skills (McDougall \& Holden, 2017; Zafar \& Nasir, 2019).

Researchers have argued that the competence in communication skills can be developed through advanced proficiencies in oral presentations (Al-Nouh, Kareem \& Taqi, 2015). Oral presentation is a planned and practiced speech that is not memorized or read from notes but is introduced by a presenter to an audience (Levin \& Topping, 2006).

One of the critical responsibilities for teachers is to present academic content in the classroom (Al-Nouh, Kareem \& Taqi, 2015; Morita, 2000). The prospective teachers are often trained to give effective oral presentations during teacher training programs and are assessed through alternative forms of assessment(Zafar \& Nasir, 2008).This allows prospective teachers to present and clarify varying concepts, ideas and content, and improve their overall self- confidence (Murphy, Hildebrand \& Thomas, 1997).

Nevertheless, in many instances, oral presentation is a rather new experience for prospective teachers and they face considerable challenges during oral presentations (Krimkhanlooei, 2017).There are many reasons behind these challenges. For example, their previous educational experiences do not foster oral presentations skills, with little or no affordances to ask questions in the classroom (Hristova, 2014). Moreover, prospective teachers feel anxiety to present and share their point of view in front of an audience(Beatty \& Friedland, 1990; Kaur \& Ali, 2018).While professional presentations require a command on language, clarity of concepts, and self-confidence (Lucas,2011); it is observed that prospective teachers coming from an English as Foreign Language (EFL) background often lose their confidence because of the difficulties to communicate in a foreign language (Miles, 2009; Yan \& Horwitz, 2008), and feel anxiety to speak in front of their peers (McCroskey \& Richmond, 1992). Similarly, in the context of present study, EFL background presents a considerable challenge to prospective teachers since their prior educational experiences were predominantly influenced by the native and local languages (Apple, 
2011). Although the medium of instruction and the content present in the textbooks are often in English Language, the classroom interaction occurs in national/local language (Urdu/Punjabi) in the schools and colleges (Ammar, Ali, Fawad \& Qasim, 2015).

The above noted challenges put forth the charge on the higher education institutions to develop skills needed for effective communication and presentations among prospective teachers in order to integrate them well in the job market (Reich, 1991). This accomplishment is possible through emergent teaching methods with student centred pedagogies that provide opportunities for students' involvement through oral presentations with continuous academic support leading to debate and sustained reasoning (Morley, 2001). In particular, the teacher training institutes need to emphasize oral presentation skills among prospective teachers (Hill \& Storey, 2003; Liow, 2008; Munby, 2011; Wolfe, 2008). They need to address the challenges of public speaking, a major fear among prospective teachers(Karimkhanlooei, 2017; Lucas, 2011) and further equip them with a range of skills required for effective presentations (Emden\& Becker, 2004) through making it a part of teaching curriculum (Hill \& Storey, 2003) most suitable to professional settings (Živković \& Stojković, 2013).

A number of researches have investigated the reasons behind the low performance of prospective teachers during oral presentations (AlNouh, Kareem \& Taqi, 2015; Chuang, 2009; Turner, Roberts, Heal \& Wright, 2012).The different factors that affect students' oral presentations are generally classified into different categories such as personal traits, lack of presentation skills and the fear of facing peers and teachers (Kaur \& Sidhu, 2009; Wolfe, 2008). Other researchers have expanded the list by including language (grammar and vocabulary), contents (ideas) and external factors such as culture and contexts (Candlin \& Mercer, 2001).

Personal traits include different factors such as shyness, selfconfidence, and physical appearance (Al-Nouh, Kareem \& Taqi, 2015). Joughin (2007) investigated the effect of personal traits on students' performance and noted that anxiety during oral presentation is one of the potential inhibiting factors that affects students' ability to perform during oral presentations.Elliot and Chong (2004) also found that one third of the sample of first-year university students in Australia had a very high level of presentation anxiety, whereas, two third of the sample of university students believed that their level of anxiety affects their performance. Not only undergraduate but graduate students were also reported being anxious during oral presentations (Morita, 2000). The anxiety was revealed through lack of eye contact, frequent mistakes with 
scarce confidence (Mostafa, 2006). Literature revealed anxiety, a major factor that poses difficulties to students as they make oral presentations, it is reported to stem from low self-confidence. Confident learners are willing to speak out and take the risks, while learners with low selfconfidence try less(Al-Hebaish, 2012).

According to Brown (1994), self-esteem plays key role in second language (L2) acquisition and is important for successful cognitive and other activities. Performance of prospective teachers is positively correlated with their self esteem (Bandura, 1997). Heyde (1983) explored the relationship between self-esteem and prospective teachers' oral performance in L2. She found that self-esteem positively correlated with oral performance. Moreover, the prospective teachers who feel that they do not have ability to present orally in L2 usually lack self-esteem.

Motivation also affects students' reluctance to speak (Nuna, 1999) especially in EFL backgrounds (Babu, 2010). Aftat (2008) emphasized that students motivation is influenced by the teachers' performance hence they should show enthusiasm to teaching itself. When students are motivated, they gain self-esteem which leads to enhanced educational achievements.

Lack of presentation skills is often seen as playing a crucial role in creating a feeling of anxiety among prospective teachers. While prospective teachers are reported to face difficulties due to English language, they also experience problems in researching, planning, organizing, and practicing their presentations (Leichsenring, 2010). Zappa-Hollman (2007a; 2007b)explored level of socialization of alien graduate students in Canada through academic oral presentation and found that they were shy and afraid to present in front of a large audience. They were afraid to give oral presentations because it involves a number of skills and commands such as communication skill, facing audience, making eye contact, content command and delivery, answering questions and handling interruptions during their presentations.

Students often lose confidence and feel that their teachers would only pay attention to the mistakes in English language(Chaung, 2010). Some prospective teachers are afraid that their peers or the teachers may judge their proficiency in English, and this makes them feel embarrassed (Chan, Yusof \& Abdullah, 2012). Watson and Friend (1969) argued that the "apprehension of other's evaluations, distress over their negative evaluations, avoidance of evaluative situations, and the expectations that others would evaluate oneself negatively" affects oral presentations. Carleton, McCreary, Norton, and Amundsen (2006) defined 
the fear of negative evaluation as "the apprehension and distress arising from concerns about being judged despairingly or hostilely by others". Prospective teachers who encounter this fear often feel worried when they are required to do oral presentations in English as they fear getting low marks from their lecturers. Kaur and Sidhu (2009) and Alwi and Sidhu (2013) found that prospective teachers' primary source of anxiety was the harsh and frightening evaluation (asking difficult questions, criticism and interruption). Speakers are not only judged by communication but they are also judged by the image or expression they transfer during communication performance (Miller, 2005). Prospective teachers may have generally negative beliefs about giving classroom presentations (Girard\& Trapp, 2011). Research indicates that many instructors do not provide explicit and appropriate scaffolding, modelling or feedback to support prospective teachers' performance of oral presentations (ZappaHollman, 2007a; 2007b). Therefore, they prefer to remain passive, and unwilling to participate in oral presentation tasks(Ross, 2007).

Juhana (2012) found linguistic indicators like lack of vocabulary, grammatical issues and incorrect pronunciation as main obstacles for students to present in the English class. Horwitz, Horwitz and Cope (1986) categorized language anxiety into communication apprehension (McCroskey, 1977)creates problems during oral presentations due to test anxiety and fear of negative evaluation. Prospective teachers are afraid of making mistakes, criticized or rejected by the audience, and have inner fear of forgetting what they want to say. Social and cultural differences, social status, self identity and gender also create problems when prospective teachers engage in oral presentations (Tanveer, 2007). Students mostly feel embarrassed or stressed during oral presentation (Mumford, 2018) especially when they present in front of the class with socio-cultural differences. A study by Tatar (2005) on Turkish students in a U.S. university found that their content, form and frequency of participation differed across different courses and situations reflecting that their participation in the classroom was influenced by context dependent factors like culture.

A common problem faced by students in a foreign context is the fear in delivering an idea orally when they have group discussion, asking question to the lecturer or even speaking in front of the class during the presentation task. When prospective teachers are presenting, they often repeat the words or sentences to overcome problem in remembering the material and consequently forget the main point that they want to convey to their audience. Ferris (1998) and Kim (2006) highlighted that most of the international students even in English-speaking countries report 
feelings of frustration when they are taking part in oral classroom tasks and formal oral presentations.

The literature discussed above notes that there are several factors that contribute to the effectiveness and quality of oral presentation such as culture, context, language, assessment anxiety and personal traits. This study explored the challenges faced by prospective teachers during oral presentations by focusing on three key factors including personal traits, lack of presentation skills, and fear of peers and teachers which are directly related to an individual during presentation in our context. This research was aimed at to identify challenges faced by prospective teachers during oral presentations in the classroom with respect to the number of semester in which the participants were enrolled (i.e., $2^{\text {nd }}$ or $\left.4^{\text {th }}\right)$, gender and GPA. There were some assumptions to address these objectives like, time spent in the program as a source of variation in facing challenges during oral presentations in the classroom due to their exposure. Gender also can be a source of variation in facing problems as male and female students have their own particular roles at homes and in the society. Moreover, the prospective teachers understanding of content matter reflected through their GPA can be a source of variation also. However, the research questions were based on these suppositions: is their significant difference on the basis of number of semester prospective teachers enrolled, gender and GPA in facing challenges during oral presentations?

\section{Methodology}

The study reported here employed a mixed method approach of inquiry by integrating both quantitative and qualitative methods to collect evidence from different sources of data in order to better understand the problem (Creswell, 2014). The combination of different methods allowed a complete understanding of the phenomenon as the researchers build on the strengths of both methods and offer alternative yet complementary perspectives on the study topic in order to present a complex picture of the situation.

\section{Research Design}

Mix method approach provides specific directions for procedures in a research design (Denzin \& Lincoln, 2011). Within this approach, an explanatory sequential mix method is employed as a research design. Consistently, the researchers analyzed quantitative data first and the results are further explained with the help of qualitative data. The design 
is considered sequential because the initial quantitative phase is followed by the qualitative phase (Tashakkori \& Teddlie, 2010; Creswell, 2014). While the design has strong quantitative orientation, it allowed the researchers to further explore the results generated from the analysis of quantitative data through qualitative methods and the unequal sample sizes for each phase of the study. For quantitative data, a questionnaire was developed with the help of literature to explore prospective teachers' opinion about the challenges faced by them during oral presentations. This quantitative exploration was followed by semi-structured interviews of prospective teachers to probe further and develop an in-depth understanding of the issues initially highlighted through the analysis of quantitative data (Creswell, 2014).

\section{Context of the Study}

The study focused on prospective teachers enrolled in teacher training institutes in the universities of the Punjab Province, Pakistan. Since the prospective teachers enrolled in different public-sector universities are more or less same in different aspects like previously studied subjects, prior schooling, socio-economic status and culture; therefore, homogeneity was assumed among prospective teachers enrolled in Masters of Education in different public-sector universities. Moreover, the problem under investigation was general in nature and assumed that there would be little diversification among candidates enrolled in public sector universities in the education discipline.

Consistently, prospective teachers enrolled at the Institute of Education and Research (IER), University of the Punjab were involved in this study. IER is a well-reputed teacher training institute entrusted for teacher education in Pakistan, catering to approximately 3000 prospective teachers every year. While the institute is not genderspecific, the number of male prospective teachers is comparatively small with respective to female. The average age of the prospective teachers is between 19 to 22 years. There are 11 departments, running 22 different degree programs with different levels and focus of specializations such as Early Childhood Education, Elementary Education, Secondary Education, Technical Education, Business Education, Science Education, and Islamic Education to cater the needs of Teacher Education Department in the Punjab Province.

The curricula taught at the Institute is designed and approved by the university bodies. Generally, a two-year Master degree program is based on four semesters each comprising six months. The assessments are distributed along three categories including mid-term exam, sessional 
work and final-term exam. Sessional work is mainly based on classroom presentations which are planned by the teachers in the classroom during the teaching of each course. The main intent of sessional work is to provide training to prospective teachers to be able to collect, organize, synthesize, and present material in the classrooms before their peers and teachers (Hill \& Storey, 2003).

\section{Variables of the Study}

Table 1 presents the details of the independent variables considered for study as a presumable source of variation among prospective teachers in facing challenges during oral presentations. The scale used to know opinion of prospective teachers regarding challenges of oral presentations highlight results against these categories of variables.

Table 1

Detail of Variables of the Study, Gender, Level of Semester and CGPA

\begin{tabular}{|c|c|c|c|c|}
\hline Sr.No. & $\begin{array}{l}\text { Independ } \\
\text { categorie }\end{array}$ & t variables of the study with & Frequency & Percent \\
\hline \multirow[t]{3}{*}{1} & Gender & Male & 60 & 15.0 \\
\hline & & Female & 340 & 85.0 \\
\hline & & Total & 400 & 100.0 \\
\hline \multirow[t]{4}{*}{2} & & 2nd Semester & 235 & 58.8 \\
\hline & Semester & & & \\
\hline & & 4th Semester & 165 & 41.2 \\
\hline & & Total & 400 & 100.0 \\
\hline \multirow[t]{4}{*}{3} & CGPA & 1.00-2.00 CGPA & 7 & 1.8 \\
\hline & & 2.1-3.00 CGPA & 157 & 39.2 \\
\hline & & 3.1-4.00 CGPA & 236 & 59.0 \\
\hline & & Total & 400 & 100.0 \\
\hline
\end{tabular}

\section{Sampling Technique}

Assuming homogeneity in prospective teachers' characteristics studying in different universities of Punjab, sample was selected from the Institute of Education and Research conveniently (Creswell, 2014). The researchers selected the participants because they were willing and available to be studied.

The sample comprised 400 prospective teachers, including both male and female, studying at IER in2nd and 4th semesters. Demographic information about the participants such as gender, GPA, and semester they were enrolled in at the time of data collection was also recorded. 
Table 2 presents the demographic information about the participants as well as distribution of the sample across different teacher education programs.

Table 2

Detail of Sample Drawn with Respect to their Program of Study and Semester

\begin{tabular}{ccccccccccc}
\hline \multirow{8}{*}{ Semester } & \multicolumn{8}{c}{ Different program of studies at IER from which students were involved in the study } \\
& $\begin{array}{c}\text { M. S. } \\
\text { Ed }\end{array}$ & M.B.E & $\begin{array}{c}\text { M.A } \\
(\text { ECE) }\end{array}$ & $\begin{array}{c}\text { M.A } \\
(\text { IE) }\end{array}$ & $\begin{array}{c}\text { MA. } \\
(\text { Ele.) }\end{array}$ & $\begin{array}{c}\text { MA } \\
(\text { Sec.) }\end{array}$ & MERA & $\begin{array}{c}\text { MA } \\
\text { (ELTL) }\end{array}$ & $\begin{array}{c}\text { B. S. } \\
\text { Ed }\end{array}$ & Total \\
\hline $2^{\text {nd }}$ & 15 & 28 & 19 & 24 & 24 & 60 & 14 & 25 & 26 & 235 \\
$4^{\text {th }}$ & 15 & 18 & 19 & 20 & 8 & 13 & 20 & 21 & 31 & 165 \\
Total & 30 & 46 & 38 & 44 & 32 & 73 & 34 & 46 & 57 & 400 \\
\hline
\end{tabular}

M. S. Ed= Master in science education; M.B.E = Master in Business Education; M.A (ECE) = Master in Early Childhood Education; M.A $(\mathrm{IE})=$ Master in Islamic Education; MA. (Ele.)= Master in Elementary Education; MA (Sec.) = Master in Secondary Education; MERA = Master in Educational Research and Assessment; MA (ELTL) = Master in English language Teaching and Literature; B. S. Ed = Bachelor in Science Education

\section{Methods of Data Collection}

Both quantitative and qualitative methods were used to collect data for the purpose of this study. A questionnaire was used to explore the challenges faced by the prospective teachers during their oral presentations in the classroom. It was based on three main factors; personal traits, presentation skills and the fear of audience (peers and teachers) as identified by the Al- Nouh, Kareem and Taqi (2015) with little modification.

The questionnaire was developed through extensive review of literature on the challenges faced during oral presentations (Morita, 2000; Elliott \& Chong, 2004; Wolfe, 2008; Chuang, 2010). It was considered an easy way to capture information from a large sample in less time (Gay \& Airasian, 2000). There were two main parts of the questionnaire. The first part recorded the demographics information and the second part comprised 24 statements spread across three sections. The sections were: personal traits ( 9 statements), presentation skills (6 statements) and peer and teachers (9 statements). Each statement was based on a five-point Likert Scale ranging from 1= strongly disagree to 5 $=$ strongly agree. 
The analysis of quantitative data highlighted five potential challenges faced by the prospective teachers during classroom presentations. It was imperative to explore the details regarding those key challenges and develop an in-depth understanding of the major issues. Consequently, a semi-structured interview based on five questions against the pre-identified challenges was designed. The questions were focused on the challenges identified through the analysis of quantitative data and allowed the researchers to collect more than one type of data to provide a rich and comprehensive picture.

\section{Pilot testing of the Questionnaire}

The instrument was pilot tested to ensure the reliability and relevance of the statements with the factors and overall accuracy (Creswell, 2012; Frenkel \& Wallen, 2009). The questionnaire was distributed to 40 prospective teachers who were enrolled in the $2^{\text {nd }}$ and $4^{\text {th }}$ semesters. They were asked to fill the questionnaire and point out any statement that is ambiguous and unclear. The questionnaires were filled and returned by with no indication of any ambiguity. The prospective teachers concurred that the questionnaire was clear, understandable and contain all salient challenges faced by them during classroom presentation. The reliability coefficient was calculated to be 0.87 that falls within the acceptable range for use (Gay, Mills \& Airasian, 2009).

Table 3

Detail of Sub-constructs, Scope, Number of Statements, an Example Statement and Reliability Coefficient of Scale

\begin{tabular}{|c|c|c|c|c|c|}
\hline Sr. & Factors & Scope & $\mathrm{N}$ & $\begin{array}{l}\text { Example from } \\
\text { Statement }\end{array}$ & Reliability \\
\hline 1. & $\begin{array}{l}\text { Personal } \\
\text { traits }\end{array}$ & $\begin{array}{l}\text { Comprises r of } \\
\text { personal feelings } \\
\text { like, anxiety, fear, } \\
\text { embarrassed, shy etc. }\end{array}$ & 9 & $\begin{array}{l}\text { I feel anxiety before oral } \\
\text { presentation in the } \\
\text { classroom }\end{array}$ & 0.876 \\
\hline 2. & $\begin{array}{l}\text { Presentatio } \\
\text { n skill }\end{array}$ & $\begin{array}{l}\text { Use of technology, } \\
\text { follow timeline, } \\
\text { English language } \\
\text { fluency etc. }\end{array}$ & 6 & $\begin{array}{l}\text { I have no experience of } \\
\text { oral presentation in my } \\
\text { prior schooling }\end{array}$ & 0.878 \\
\hline 3. & $\begin{array}{l}\text { Peers and } \\
\text { teacher }\end{array}$ & $\begin{array}{l}\text { Facing peers \& } \\
\text { teacher, assessment } \\
\text { fear, speaking in } \\
\text { front of class etc. }\end{array}$ & 9 & $\begin{array}{l}\text { The teacher's } \\
\text { interruption during } \\
\text { presentation affects my } \\
\text { performance }\end{array}$ & 0.874 \\
\hline
\end{tabular}

$\mathrm{N}=$ Number of statements 


\section{Data Collection and Analysis Procedures}

The questionnaires were distributed to the 2 nd and 4 th semester prospective teachers enrolled in different programs at IER. The coresearchers approached them in their classrooms and stayed with them until they completed and returned the questionnaires. Overall, the research team visited 18 classes running under different programs to collect data. The total number of completed and returned questionnaires was 400 .

Quantitative data were entered into SPSS, cleaned and organized for analysis. The scale was analysed and presented descriptive by following criteria: low for mean scores from 1.00 to 2.33 , medium for mean scores from 2.34 to 3.66, and high for mean scores from 3.67 to 5.00 (Al-Nouh, Kareem \&Taqi, 2015). T-test was applied on data of two independent variables gender and number of semester having two categories and ANOVA was used to see difference on the basis of GPA having three categories. The main issues that emerged from the analysis of quantitative data were stand-alone facts that required further probing so semi-structured interview were also used.

Thirty prospective teachers were selected from the 400participants for interview in the second phase of data collection. They were selected on the basis of convenience and availability. They were asked different questions in order to explore the reasons behind the challenges faced by prospective teachers during oral presentations. Interviews were conducted by the co-researchers on one to one basis and were audio recorded. Each interview lasted for about 7-10 minutes.

Data collected through student interviews were transcribed, coded, analyzed, and explored through a qualitative data analysis software package, NVivo 10. The recorded interviews were transcribed for meaning and the process of transcription helped the researchers to developed a deeper understanding of the issues through repeatedly listening to the audio recordings and reading the interview transcripts. Thematic analysis was conducted on the qualitative data that allowed the researchers to move from specific chunks of data to shared meanings and interpretations through iterative and inductive cycles of data analysis (Smith, 2004).

\section{Ethical Considerations}

The researchers considered the rights and respect of the respondents (Creswell, 2008) and sought their consent for participation in the study. Prospective teachers were explained the purpose, scope and details of the study and were given the chance to ask questions. The identity of the participants was neither required for the purpose of the 
study nor was it recorded in any form.

\section{Results}

\section{Quantitative Results}

Descriptive results are presented factor wise in the following paragraphs. The results regarding first factor personality traits shows medium level scores in regard to facing challenges during oral presentations. They felt anxiety before oral presentation $(\mathrm{M}=2.98)$ lacking of English language fluency $(\mathrm{M}=2.87)$ and consequently the speaking ability $(\mathrm{M}=2.83)$. Even they get worried if well prepared before presentation ( $\mathrm{M}=2.88)$ owing to forgetting or fear of forgetting content during presentation $(\mathrm{M}=2.69)$. Mostly students take in mind that their peers are better in speaking English and lose confidence $(M=2.94)$. Students previous negative experience regarding oral presentation also make them confuse and effect their performance $(M=2.28)$. Fear of having low grades in the assessment of presentation $(\mathrm{M}=2.59)$ is also a source of challenge for students during presentation. Students are less confident and feel shy to present $(\mathrm{M}=2.74)$ in the classroom.

The results related to second factor, presentation skills are also showing moderate level scores against different statements of this factor. The results reveal that participants of the study faced problems of medium rank in the use of technology during oral presentations $(\mathrm{M}=$ 2.56). They found it moderately difficult to complete the presentations in the given time period $(\mathrm{M}=2.85)$. The language is more concern of the prospective teachers as compare to content they are going to present in the class $(M=2.92)$ especially issue of pronunciation $(M=2.79)$. Prior education (schooling) have little focus on presentation $(\mathrm{M}=2.94)$. The clarity of content to be delivered is also a source of problem with moderate mean score $(\mathrm{M}=2.79)$.

The descriptive results of third factor, peers and teachers are consistent with previous both factors of oral presentations. Prospective teachers feel nervous that others students are watching them $(\mathrm{M}=2.90)$. As they are not good at speaking English and think peers will laugh at him $(M=2.73)$ and especially teacher will mind on my mistakes during presentation $(\mathrm{M}=2.89)$. Even teacher will interrupt me during presentation $(\mathrm{M}=2.96)$ is a continuous source of anxiety for them. Prospective teachers avoid to make eye contact to their teacher during oral presentation $(\mathrm{M}=2.85)$ and afraid conferring low grade in assessment of presentation $(M=2.89)$. Moreover, peer reactions $(M=2.98)$, interruptions by peers $(\mathrm{M}=2.92)$ and the quality of their voice during 
oral presentations $(\mathrm{M}=2.90)$.

Table 4 showed cumulative descriptive results against all factors of oral presentations scale. The challenges faced by the participants in the study are of medium rank related to personal traits $(\mathrm{M}=2.76)$, presentation skills $(\mathrm{M}=2.80)$ and peer and teachers $(\mathrm{M}=2.90)$. The major challenge of oral presentation is audience and minor personal traits comparatively but with little mean difference. Whereas mean values of all factors of oral presentations are evidently supporting to cause difficulties for the participants during presentations. They are specifically anxious to present in front of their peers considering them better in speaking English. These results are consistent with the results from the studies conducted in different countries (Wolfe, 2008; Al-Nouh, Kareem \& Taqi, 2015).

Table 4

Prospective Teachers Opinions on Scale related to Challenges during Oral Presentations

\begin{tabular}{clcccccc}
\hline $\begin{array}{l}\text { Sr. } \\
\text { No }\end{array}$ & $\begin{array}{l}\text { Sub- } \\
\text { constructs }\end{array}$ & Minimum & Maximum & Mean & SD & Mean/item & Rank \\
\hline 1 & $\begin{array}{l}\text { Personal } \\
\text { Traits }\end{array}$ & 9.00 & 45.00 & 24.81 & 7.07 & 2.76 & Medium \\
2 & $\begin{array}{l}\text { Presentation } \\
\text { Skills }\end{array}$ & 6.00 & 30.00 & 16.78 & 4.27 & 2.80 & Medium \\
3 & $\begin{array}{l}\text { Peers and } \\
\text { teachers }\end{array}$ & 9.00 & 45.00 & 26.08 & 7.07 & 2.90 & Medium \\
\hline
\end{tabular}

$\mathrm{N}=400$

Table 5 represents difference in the opinions of prospective teachers on the basis of gender regarding the challenges involved in oral presentation. It shows that female students mean score on overall scale of oral presentation challenges is less as compare to male students. The factor wise mean scores of male and female students are, personal factor $(24.85,24.80)$, presentation skills $(17.17,16.71)$ and peers and teachers $(26.85,25.87)$ respectively. But there is no significant difference against factors of oral presentation challenges except for peers and teachers $[\mathrm{t}$ $(398)=.990, \mathrm{P}=.045]$. The significant difference in factor peers and teachers shows that male prospective teachers reportedly face more anxiety, nervousness, and fear of presentation in a second language as compared to their female peers. Likewise, mean scores of female prospective teachers in both factors; personal traits and presentations skills are low as compared to male participants which implies that female prospective teachers face less challenges during presentation when compared to the male participants. 
Table 5

Gender-wise Comparison of Prospective Teachers' Opinion against Challenges of Oral Presentation Scale

\begin{tabular}{llllcccc}
\hline Sr. & Sub- construct & Gender & $\mathrm{N}$ & Mean & $t$ & $d f$ & Sig. \\
\hline 1 & Personal Traits & Male & 60 & 24.85 & .047 & 398 & .781 \\
& & Female & 340 & 24.80 & & & \\
2 & $\begin{array}{l}\text { Presentation } \\
\text { Skills }\end{array}$ & Male & 60 & 17.17 & .760 & 398 & .211 \\
& Female & 340 & 16.71 & & & \\
3 & $\begin{array}{l}\text { Peers and } \\
\text { teachers }\end{array}$ & Male & 60 & 26.85 & .990 & 398 & .045 \\
& & Female & 340 & 25.87 & & & \\
\hline
\end{tabular}

Table 6 shows results of the differences against the number of semester in which the prospective teachers were enrolled in at the time of data collection activity. The results show that the participants enrolled in the $2^{\text {nd }}$ and $4^{\text {th }}$ semester have no significant difference in the performance of oral presentations. It is evident that prospective teachers enrolled in $2^{\text {nd }}$ semester have more mean scores on all factors of oral presentation scale $(25.62,17.23,27.19)$ when compared to the ones enrolled in the $4^{\text {th }}$ semester $(23.64,16.13,24.34)$ respectively which showed students faced least challenges with passage of time. The higher semester mean spent more time at the institute decrease the challenges of oral presentations faced by the students.

Table 6

Semester-wise Comparison of Prospective Teachers' Opinions related to Challenges of Oral Presentation

\begin{tabular}{cccccccc}
\hline Sr. & Factor & Semester & $\mathrm{N}$ & Mean & $t$ & $d f$ & Sig. \\
\hline 1 & Personal Traits & $2^{\text {nd }}$ & 235 & 25.62 & 2.77 & 398 & .562 \\
& & $4^{\text {th }}$ & 165 & 23.64 & & & \\
2 & $\begin{array}{c}\text { Presentation } \\
\text { Skills }\end{array}$ & $2^{\text {nd }}$ & 235 & 17.23 & 2.55 & 398 & .325 \\
& & $4^{\text {th }}$ & 165 & 16.13 & & & \\
& & & & & & \\
3 & $\begin{array}{c}\text { Peers and } \\
\text { teachers }\end{array}$ & $2^{\text {nd }}$ & 235 & 27.19 & 4.04 & 398 & .104 \\
& & $4^{\text {th }}$ & 165 & 24.34 & & & \\
\hline & & & & & & &
\end{tabular}


Table 7 represents results of participants' opinion about personal traits on the basis of GPA. The results reveal( $F=1.789, \mathrm{df}=2$ and $\mathrm{p}=.169)$; which shows that there is no significant difference between participants' opinion on personal traits on the basis of their GPA mean grade does not matter towards level of challenges faced by the students during oral presentations. In other words, GPA does not affect the personal traits during oral presentation. It is intriguing since it is generally assumed that academically advanced learners are more capable to share, communicate and present due to good content knowledge and reading habits (Amirian, Reza, \& Elaheh, 2016).

Table 7

Participants' Opinion about Personal Traits Based on their GPA

\begin{tabular}{clccccc}
\hline Sr. & Groups & Sum of Squares & $d f$ & $\begin{array}{c}\text { Mean } \\
\text { Square }\end{array}$ & F & Sig. \\
\hline 1. & Between Groups & 178.030 & 2 & 89.015 & 1.789 & .169 \\
& Within Groups & 19757.530 & 397 & 49.767 & & \\
& Total & 19935.560 & 399 & & & \\
\hline
\end{tabular}

Table 8 represents results of participants' opinion about presentation skills on the basis of participants' GPA, $(\mathrm{F}=1.905, \mathrm{df}=2$ and $\mathrm{p}=.150)$. There is no significant difference of presentation skills on the basis of participants' GPA in facing challenging during oral presentations.

Table 8

\begin{tabular}{clccccc}
\multicolumn{6}{c}{ Participants' Opinion about the Presentation Skills } & Based \\
\hline Sr. & Groups & Sum of & $d f$ & Mean & F & Sig. \\
& & Squares & & Square & & \\
\hline 2. & Between Groups & 69.214 & 2 & 34.607 & 1.905 & .150 \\
& Within Groups & 7213.426 & 397 & 18.170 & & \\
& Total & 7282.640 & 399 & & & \\
\hline
\end{tabular}

Table 9 shows results of participants' opinion about peers and teachers on the basis of GPA, demonstrates that $\mathrm{F}=2.189$, $\mathrm{df}=2$ and $\mathrm{p}=0.113$; showing there is no significant difference in participants' opinion related to factor, peers and teaches on the basis of their GPA. In other words, GPA does not affect students' opinion about the influence of peers and teachers during oral presentation. 
Table 9

Participants' Opinion about the Influence of Peers and Teachers Based on their GPA

\begin{tabular}{clccccc}
\hline Sr. & Groups & Sum of Squares & $d f$ & Mean Square & F & Sig. \\
\hline 3. & Between Groups & 217.262 & 2 & 108.631 & 2.189 & .113 \\
& Within Groups & 19703.616 & 397 & 49.631 & & \\
& Total & 19920.877 & 399 & & & \\
\hline
\end{tabular}

\section{Qualitative Results}

The major results that emerged from quantitative analysis of data were further explored through semi-structured interviews with 30 participants. The participants were asked questions about the challenges that may occur due issues related to language, technology, personal traits, and audience during oral presentations. The main patterns that emerged from the analysis of qualitative data are presented in Table 10.

Table 10

Interview Questions and Responses of Prospective Teachers with Frequency and Percentage

\begin{tabular}{|c|c|c|c|c|c|}
\hline \multirow[t]{2}{*}{$\mathrm{Sr}$. } & \multirow[t]{2}{*}{$\begin{array}{l}\text { Statements for probing } \\
\text { reasons }\end{array}$} & \multirow[t]{2}{*}{$\mathrm{N}$} & \multicolumn{3}{|c|}{$\begin{array}{l}\text { Reasons Reported by prospective teachers with } \\
\text { frequency }(\%)\end{array}$} \\
\hline & & & 1 & 2 & 3 \\
\hline 1. & $\begin{array}{l}\text { How does English language } \\
\text { affect your oral } \\
\text { presentations? Explain. }\end{array}$ & 30 & $\begin{array}{l}\text { Prior schooling } \\
\text { experience in } \\
\text { public sector } 8 \\
(26 \%)\end{array}$ & $\begin{array}{l}\text { Rote } \\
\text { memorization } 5 \\
(17 \%)\end{array}$ & $\begin{array}{l}\text { Lack of } \\
\text { experience of } \\
\text { speaking } \\
\text { English } \\
\text { language } \\
17(57 \%)\end{array}$ \\
\hline 2. & $\begin{array}{l}\text { What linguistic factors are } \\
\text { challenging for you during } \\
\text { classroom presentation? }\end{array}$ & 30 & $\begin{array}{l}\text { Fear of } \\
\text { Grammatical } \\
\text { errors during } \\
\text { presentation } \\
08(27 \%)\end{array}$ & $\begin{array}{l}\text { Afraid Wrong } \\
\text { pronunciation } \\
\text { during } \\
\text { presentation } \\
10(33 \%)\end{array}$ & $\begin{array}{l}\text { Lack of } \\
\text { vocabulary } \\
\text { knowledge to } \\
\text { speak in } \\
\text { English } \\
12(40 \%)\end{array}$ \\
\hline 3. & $\begin{array}{l}\text { What are the challenges that } \\
\text { you personally feel when } \\
\text { you are presenting in front } \\
\text { of the class? }\end{array}$ & 30 & $\begin{array}{l}\text { Lack of } \\
\text { confidence to } \\
\text { stand before the } \\
\text { class } 17(57 \%)\end{array}$ & $\begin{array}{l}\text { Shyness to face } \\
\text { teachers and } \\
\text { peers } \\
7(23 \%)\end{array}$ & $\begin{array}{l}\text { Lack of eye } \\
\text { contact during } \\
\text { presentation } 6 \\
(20 \%)\end{array}$ \\
\hline 4. & $\begin{array}{l}\text { What are the issue that you } \\
\text { face when you use } \\
\text { technology (computer, } \\
\text { laptop, projectors etc) during } \\
\text { presentation in the } \\
\text { classrooms? }\end{array}$ & & - & $\begin{array}{l}\text { Worried that } \\
\text { my } \\
\text { presentation } \\
\text { will not work } \\
\text { on multimedia } \\
21(70 \%)\end{array}$ & $\begin{array}{l}\text { Electric load } \\
\text { shedding limit } \\
\text { use of devices } \\
\text { during } \\
\text { presentation } 9 \\
(30 \%)\end{array}$ \\
\hline 5. & $\begin{array}{l}\text { How does the audience } \\
\text { influence your classroom } \\
\text { presentation? }\end{array}$ & 30 & $\begin{array}{l}\text { Teacher's } \\
\text { interruption } 15 \\
(50 \%)\end{array}$ & $\begin{array}{l}\text { Classmate's } \\
\text { interruption } \\
15(50 \%)\end{array}$ & - \\
\hline
\end{tabular}


Data from the study suggests that the main challenge reported by the participants of the study was a lack of proficiency in English Language. The main issues raised in this context were fluency, vocabulary, grammar and speaking skills (AbuAl-Enein, 2011). In particular, the participants raised three main issues including lack of exposure to English language, previous schooling experiences and rote memorization instead of understanding the concepts. It was apparent from their comments that their prior educational experiences were in their native language. For example, one participant pointed out: "Second language affects my performance because I studied in public schools where teachers did not pay attention to spoken English". Moreover, the participants had little to no exposure to projects, assignments and oral presentations during their school years. While it is a challenge to speak in non-native language in itself (Krimkhanlooei, 2017), but the problem worsens in the absence of little to no relevant exposure and experiences. This urges learners to try to memorize the content for oral presentations which they eventually forget due to anxiety and nervousness (Leichsenring, 2010). While rote memorization has negative consequences for the learners in most of the cases, the participants of the study seemed to have no other choice as one of the participants argued:

Yes, second language affects my presentation because it is not our native language. I cannot speak well in English when compared to Urdu. I read English just in the textbook and did not take interest in speaking English. I memorized the facts ... Now, at the university level, I face challenges about speaking English during presentations. It affects my performance because some teachers deduct my marks as I make mistakes while presenting in a second language.

Another concurred:

Yes, lack of experience in speaking English is the reason behind it, because in schools and colleges teachers do not prefer to speak English. When we enter the university, we cannot speak in front of the class due to no prior experience.

The participants reported three main issues that limit their language capabilities during oral presentations. These include: lack of vocabulary, fear of wrong pronunciation and grammatical errors. For example, one of the participant mentioned during the interview: "I am worried about wrong pronunciation when giving presentation in the classroom . . . I make grammatical error and speak wrong sentences during presentation." Another mentioned: "I do not have enough vocabulary to explain the ideas and concepts that are in my mind during 
presentations." Eventually, participants opt for rote memorization during oral presentations.

As for the personal factors that affect participants' classroom presentations, it was reported that the participants lack confidence which was the main reason behind their difficulties during the process. For example, one of the participants mentioned: "I lose confidence when I come in front of the class to present something, when I come to the rostrum, my legs start shivering." Other factors include shyness ("I feel shy when my classmates watch me during presentation") and the inability to establish eye contact with the audience ("I do not make proper eye contact with the audience and the teacher during presentation because I am afraid of the teacher for making negative evaluation"). These limitations on the part of the participants are due to little prior experiences and training related to public speaking and oral presentations. Generally, students have limited opportunities to share and communicate ideas within the context of the study (Endo, 2008).

The participants of the study also mentioned some issue with the use of digital technology and latest advancement while preparing for classroom presentations. Most of them mentioned having little to no prior exposure to digital technologies such as computer, power point slides, web browsing etc. For example, one participant mentioned: "I am worried about the use of computers in searching relevant material that is necessary in making slides. So, the inability to use technology affects my presentation." Other than that, electricity shortfall was among salient factors that affects students' ability to prepare for and perform during oral presentations. One of the participants noted:

I am worried about the use of multimedia in my presentation because of frequent short fall of electricity. I always worry before and during my presentation that the power would be shut down and I would not be able not present properly. I like to prepare power point slides using pictorials like graphs and pictures and present via multimedia.

Lastly, it was apparent from the participants' comments during oral presentations that they were concerned about interruptions during their presentations. In particular, they get annoyed when the face interruptions from their peers, as one of the participants explained: "When classmate interrupts during the presentation, it affects my performance, because the flow of my presentation is affected by their interruption." Moreover, they mentioned that they get confused when the teacher interrupts them and asks them a question. They felt uneasy and anxious that they would receive low grades. 


\section{Discussion of Results}

This study examined the challenges faced by prospective teachers during classroom oral presentations. The analysis of quantitative data revealed that the majority of the participants find oral presentations moderately challenging for themselves. In particular, they reported the feelings of anxiety and lack of confidence. While there were no significant differences found in the opinion of males and female prospective teachers regarding the challenges faced during oral presentations, female participants reported feeling less threatened by the audience than their male colleagues. These findings are context specific and can be more meaningfully interpreted by refereeing to the number of male and female participants in the study. The sample predominantly comprises females; male participants are few in number. This is because males generally do not join teaching profession as their first choice. They only get enrolled in a teacher training program when they have no chance of getting enrolled in the discipline of their choice. On the other hand, teaching profession is the first preference for many female prospective teachers (Nelson, 2003). Moreover, results of the studies conducted in the local context also show that females are hardworking, committed and focused on their studies when compared to their male counterparts.

Moreover, participants enrolled in the $4^{\text {th }}$ semester reportedly faced less difficulties during oral presentations than the $2^{\text {nd }}$ semester participants. Interestingly, no significant difference was found on the basis of participants' GPA and the difficulties faced during oral presentations. This may be because with the passage of time, participants gain more experience with respect to class presentations that enable them to control their anxiety during presentations and develop the confidence to face their peers and teachers (Raja, 2017).

An in-depth analysis of qualitative data suggests that the participants of the study grappled with the complexities of presenting in English, a foreign language. This is because most of the participants are not well conversant in English, and therefore, find it challenging to cope with the language barriers during oral presentations. These findings are consistent with other studies (AbuAl-Enein, 2011; Babu, 2010; Chuang, 2010;). Moreover, the participants were concerned about the fear of negative evaluation, use of technology, and interruption from the audience during classroom presentations. These findings suggest that the prospective teachers who participated in the study were not wellequipped with the necessary skills and attitudes needed for classroom presentations. Similar findings are put forth by researchers who argued 
that lack of presentation skills were seen to play a crucial role in students' feelings of anxiety Leichsenring, 2010) students feared oral presentations as it involved a number of skills (Zappa-Hollman, 2007a).

\section{Implications of the Study}

The study highlighted main challenges of oral presentation reported by prospective teachers. The results are aligned with the literature and render second language as a big challenge of oral presentation. The ideas emerged and processed in the mind could not articulate due to lack of vocabulary, little knowledge of sentence structure/grammar and pronunciation even. The bundle of such thoughts captured the minds of the prospective teachers and they become anxious, nervous and frustrated. Moreover, the exposure and experience of presentation skill is lacking in our schools and colleges which increase challenges of prospective teachers. The main issues faced by prospective teachers are synthesized along with embedded reasons behind them. There is need to address these issues by taking some solid steps like, develop some labs like language, IT, audio \& video and discussion forums to give variety of opportunities to help prospective teachers in developing language and communication skills. In schools and colleges teachers should engage students' in classroom activities to become active and confident learners. The environment of institutes should provide a platform to prospective teachers for sharing and collaborating to each other which result in confident with high self- respected learners. 


\section{References}

Abu El Enein, A.H. (2011). Difficulties encountering English majors in giving academic oral presentations during class at Al-Aqsa University. (PhD Thesis), Gaza, Islamic University of Gaza.

Aftat, M. (2008). Motivation and Genuine learning. [Online] Available: http://www.englishteacher1.com/motivation.html (March 15, 2011).

Al-Hebaish, S. M. (2012). The correlation between general self-confidence and academic achievement in the oral presentation course. Theory and Practice in Language Studies, 2(1), 60-65.

Al-Nouh, N. A., Abdul-Kareem, M. M., \& Taqi, H. A. (2015). EFL College Students' Perceptions of the Difficulties in Oral Presentation as a Form of Assessment. International Journal of Higher Education, 4(1), 136.

Alwi, N.F.B., \& Sidhu, G.K. (2013). Oral presentation: Self-perceived competence and actual performance among UiTM Business faculty prospective teachers. Procedia-Social and Behavioral Sciences, 90, 98106.

Amirian, Reza, M. S., \& Elaheh, T. (2016). Academic Oral Presentation SelfEfficacy: A Cross Sectional Interdisciplinary Comparative Study. Higher Education Research and Development, 35(6), 1095-1110

Ammar, A., Ali, N., Fawad, A., \& Qasim, K. (2015). Language policy and medium of instruction in Pakistan. Acta Linguistica Asiatica, 5(1), 111123.

Babu, R. (2010). Teaching Spoken English for Non-native Prospective teachers: Problems, Solutions and Techniques. Available [Online]:http://www.eltweekly.com/elt-newsletter. 
Bandura, A. (1997). Self-efficacy: The exercise of control. New York: W.H. Freeman and Company.

Beatty, M.J., \& Friedland, M. H. (1990). Public speaking state anxiety as a function of selected situational and predispositional variables. Communication Education, 39, 142-147.

Brown, H. D. (1994). Principles of language learning and teaching. Englewood Cliffs, NJ: Prentice-Hall.

Campbell, K. S., Mothersbaugh, D. L., Brammer, C., \& Taylor, T. (2001). Peer versus Self-Assessment of Oral Business Presentation Performance. Business Communication Quarterly,64(3), 23-42.

Mercer, N., \& Candlin, N. (2001). English Language Teaching in Its Social Context. TESOL Quarterly, 35 (4), 617-618.

Carleton, N., McCreary, D., Norton, P., \& Asmundson, G. (2006). Brief fear of negative evaluation scale revised. Depression and Anxiety, 23, 297303.

Chan, S. H., Abdullah, A. N., \& Yusof, N. (2012). The construct of anxiety and the relationship to speaking skills among ESL tertiary learners. $3 \mathrm{~L}$ : The Southeast Asian Journal of English Language Studies, 18 (3), 155166.

Chuang, Y. Y. (2010). A study of using Task-based Approach to teach EFL speaking. Journal of National Formosa University, 29(4), 37-52.

Creswell, J. W. (2008). Research design: Qualitative, quantitative, and mixed methods approaches. California, USA: Sage Publications.

Creswell, J. W. (2012). Educational research: planning, conducting, and evaluating quantitative and qualitative research. Boston: Pearson.

Creswell, J. W. (2014). Research Design: Qualitative, quantitative and Mix methods approaches $\left(4^{\text {th }}\right.$ ed.)Thousand Oaks, CA: Sage.

Creswell, J.W. (2015). A concise introduction to mixed methods research. Thousand Oaks, CA: Sage. 
Denzin, N., \& Lincoln, Y. S. (Eds.). (2005). Introduction: The Discipline and Practice of Qualitative Research. Thousand Oaks, CA: Sage Publications.

Elliott, J.,\& Chong, J.L.Y. (2004). Presentation anxiety: A challenge for some prospective teachers and a pit of despair for others. Challenging education: Socio-cultural, economic and academic outcomes: Proceedings of the $15^{\text {th }}$ ISANA International Conference, 2004, 30 November-3 December, 2004, Grand Hayatt, Melbourne, Victoria.

Emden, J., \& Becker, L. (2004).Presentation Skills for Prospective teachers: Houndmills, Basingstoke, Hampshire. Palgrave Macmillan.

Endo, K. (2008). Transforming reticent students to oral presenters. JALT 2007 Conference Proceedings, 653-667.

Ferris, D. (1998). Prospective teachers' views of academic aural/oral skills: a comparative needs analysis. TESOL Quarterly, 32, $289-318$

Fraenkel, J.R., \& Wallen, N.E. (2009). How to design and evaluate research in education. New York: McGraw-Hill.

Gay, L.R., \& Airasian, P. (2000). Educational research: competencies for analysis and application ( $6^{\text {th }}$ ed.). Upper Saddle River, NJ: Pearson.

Gay, L.R., Mills, G.E., \& Airasian, P. (2009). Educational research: competencies for analysis and application. Upper Saddle River, NJ: Pearson.

Girard, M. P., \& Trapp, P. (2011). An exploratory study of class presentations and peer evaluations: Do prospective teachers perceive benefits? Academy of Educational Leadership Journal, 15(1), 77-94.

Harman, K.E.(2010).Innovations in coordinating undergraduate students' oral tutorial presentations. Journal of University Teaching and Learning Practice, 7(1),1-13.

Hill, M., \& Storey, A. (2003). Speak Easy: Online support for oral presentation skills. English Language Teaching Journal, 57(4), 370-376. 
Horwitz, E. K., Horwitz, M. B., \& Cope, J. (1986). Foreign language classroom anxiety. The Modern Language Journal, 70, 125-132.

Hristova, Z. (2014). Using Peers to Assess Oral Presentations to Foster Learning. International Journal of Innovation in Science and Mathematics Education,22(3), 74-80.

Juhana, J. (2012). Linguistic factors that become students' obstacles to speak in English class. Ragam Jurnal Pengembangan Humaniora, 12(2), 6377 .

Joughin, G. (2007). Student conceptions of oral presentations. Studies in Higher Education, 32(3), 323-336.

Karimkhanlooei, G. (2017). Attitude of students of medicine toward oral presentations as part of the ESP course. Higher Education of Social Science, 12(2), 42-48

Kaur, K., Ali, M. A. (2018). Exploring the Genre of Academic Oral Presentations: A Critical Review. International Journal of Applied Linguistics \& English Literature, 7(1).

Kaur, S. \& Sidhu, G. K. (2009). A qualitative study of postgraduate prospective teachers' learning experiences in Malaysia. International Education Studies, 2(3), 47-56.

Kim, S. (2006). Academic oral communication needs of East Asian international graduate prospective teachers in non-science and nonengineering fields. English for Specific Purposes, 25, 479-489.

Leichsenring, A. (2010). What do 1st year Japanese EFL prospective teachers learn by preparing and presenting a group work oriented oral presentations? Online submission to the Institute of Education Sciences, ED 537529. Retrieved Friday 18th April from http://eric.edu.gov./

Levin, P., \& Topping, G. (2006). Perfect presentations. Berkshire, England: Open University Press. In Irvine, L. Orals ain't orals: How instructions and assessment practices affect delivery choices with prepared student oral presentations. Paper presented at the Australian and New Zealand Communication Association Conference, Brisbane. 
Liow, J. (2008). Peer assessment in thesis oral presentation. European Journal of Engineering Education, 33(5) (6), 525-537.

Luca, S.E. (2001). The art of public speaking. New York, NY: McGrawHill.

McCroskey, J. C. (1977). Oral communication apprehension: A summary of recent theory and research. Human Communication Research, 4, 78-96.

McCroskey, J. C., \&Richmond, V. P. (1992). Communication apprehension and shyness: Conceptual and operational distinction. Central States Speech Journal, 33, 458-468.

McDougll, J.,\& Holden, H. (2017). The silence about oral presentation skills in distance and online education: new perspectives from an Australian university preparatory programme, Open Learning: The Journal of Open, Distance and e-Learning, 32(2), 163-176.

Miles, R. (2009). Oral presentations for English proficiency purposes. Reflections on English Language Teaching, 8 (2), 103-110.

Miller, P. W. (2005).Body Language: An Illustrated Introduction for Teachers. Patrick W. Miller Associates.

Morita, N. (2000). Discourse socialization through oral classroom activities in a TESL graduate program. TESOL Quarterly, 34, 279-311.

Morley, L. (2001). Producing New Workers: Quality, Equality and Employability in Higher Education. Quality in Higher Education, 7(2), 131-138.

Mostafa, G.M.M. (2006). Learning and Cultural Experiences of Arab Muslim Graduate Students in a Canadian University. Journal of Contemporary Issues in Education, 1(1), 36-53.

Mumford, S. (2018). Understanding the Challenges of Academic Presentations for EAP Students: An Exploratory Practice Approach. Developing Language Teachers with Exploratory Practice. Springer International publishing: Switzerland

Munby, I. (2011). The oral presentation: An EFL teachers' toolkit. Studies in Culture, 99, 143-168. 
Murphy, H. A., Hildebrandt, H.W., \& Thomas, J.P. (1997). Effective Business Communications ( $7^{\text {th }}$ ed.). New York: McGraw-Hill.

Nelson, B. (2003). Primary schools need more male teachers: Media Release $27 \mathrm{Feb}, 2003$. MIN 291/03.

Nunan, D. (1999). Second Language Teaching \& Learning. USA: Heinle \& Heinle Publisher.

Raja, F. (2017). Anxiety Level in Students of Public Speaking: Causes and Remedies. Journal of Education and Educational Development, 4(1), 94110 .

Reich, R. (1991). The work of nations: Preparing ourselves for $21^{s t}$ century capitalism. New York: Knopf.

Ross, E. (2007). Are oral classroom presentation s necessary? Insights into TEFL. Retrieved from http:// insights-into-tefl.blogspot.com.

Smith, J. A. (2004).Reflecting on the development of interpretative Phenomenological analysis and its contribution to qualitative research in Psychology. Qualitative Research in Psychology, 1(1), 39-54.

Tanveer, M. (2007). Investigation of the factors that cause language anxiety for ESL/EFL learners in learning speaking skills and the influence it casts on communication in the target language. (Unpublished Master's thesis), University of Glasgow, Scotland.

Tashakkori, A., \& Teddlie, C. (2010). SAGE handbook of mixed methods in social and behavioral research ( $2^{\text {nd }}$ ed.). Thousand Oaks, CA: Sage.

Tatar, S. (2005). Why keep silent? The classroom participation experiences of non-native-English-speaking prospective teachers. Language and Intercultural Communication. 5(3\&4), 284-293

Thornbury, S. (2005). How to teach speaking. Harlow: Pearson Education.

Turner, K., Roberts, L., Heal, C.,\& Wright, L. (2012). Oral presentations as a form of summative assessment in a master's level PGCE module: The student perspective. Assessment \& Evaluation in Higher Education, $38(6), 662-673$. 
Watson, D., \& Friend, R. (1969). Measurement of social evaluative anxiety. Journal of Consulting and Clinical Psychology, 33, 448-457.

Wolfe, A. (2008). Oral presentations in marketing courses: Prospective teachers' attitudes and self-assessment. Presentation \& Paper published in the proceeding in the Marketing Management Association (MMA) $13^{\text {th }}$ Annual Fall Educators Conference, Louisville, Kentucky.

Yan, J. X., \& Horwitz, E. K. (2008). Learners' perceptions of how anxiety interacts with personal and instructional factors to influence their achievement in English: A qualitative analysis of EFL learners in China. Language Learning: A journal of research in language studies, 58, 151183.

Zafar, I., \& Nasir, M. (2008). Compatibility of peer assessment and teacher assessment in observational situations: An emerging assessment tool in higher education Bulletin of Education and Research, 30(2), 61-77.

Zafar, I., \& Nasir, M. (2019). Linguistic Choices of Interlocutors in the classroom and

Understanding of Science. Journal of Social Sciences and Humanites, 27(1), $127-154$.

Zappa-Hollman, S. (2007a). Becoming socialized into diverse academic communities through oral presentations. Canadian Modern Language Review, 63(4), 455-485.

Zappa-Hollman, S. (2007b). The academic literacy socialization of Mexican exchange students at a Canadian university. (Unpublished doctoral dissertation), University of British Columbia, Vancouver, Canada.

Živković, S., \&Stojković, N. (2013). To Modernize or not to Modernize There is no Question. Academic Journal of Interdisciplinary Studies, 2(11), 70-76.

Citation of this Article:

Iqbal, Z., Alvi, E., \& Shafi, F. (2019). Prospective teachers' perceptions of oral presentations: An exploration of challenges involved. Pakistan Journal of Education, 36(2), 137-163. 